process of forming social capital and the related undertakings undertaken within the existing institutional order are not sufficiently exposed, as well as the content relevant to the stage of human activity. In this situation, it seems justified to postulate effective forms of education in the field of social capital formation in the education process, which requires undertaking more extensive research on the subject matter and debate on how to implement the conclusions resulting from this research.

Keywords: human capital, social capital, education, knowledge economy.

DOI: https://doi.org/10.31392/NZ-npu-145.2019.26

УДК 378.091 .27

Оленєв Д. Г.

\title{
ВПЛИВ АКТИВНОГО ВІДПОЧИНКУ НА СТАН М'ЯЗОВОГО ТОНУСУ ПРИ МАЛОРУХЛИВІЙ ПОСТАВІ
}

3 а результатами досліджень понад 60,0\% студентів-першокурсників мають різні психосоматичні відхилення у стані здоров'я $і$ з кожним наступним роком навчання у вищому навчальному закладі ия кількість збільшується. Актуальною проблемою у підготовці фахівців у галузі телекомунікаційних та інформаційних технологій є недостатня рухова активність, яка сприяє інтенсивному розвитку процесів гіподинамії. Внаслідок иььго очевидна необхідність щодо впровадження здоров'язбережувальних технологій у навчальний процес студентів вищих навчальних закладів телекомунікаиійних та інформаційних технологій.

Загальновідомо, щчо ті фізичні вправи, до яких організм погано адаптований (наприклад, біг), виявляються найціннішими в умовах обережного, суворо дозованого використання. Будьяка фізична вправа може бути виключена лише на деякий час, після чого ї̈ треба поступово включати у заняття. Заборона будь-яких вправ за медичними показниками через погане пристосування організму до їх виконання може стосуватися тих рухів, які не мають прикладного значення, наприклад, деякі гімнастичні вправи, як-то “шпагат”. Жодна фізична вправа, яка має прикладне значення, не може бути протипоказаною взагалі, без визначення періоду, впродовж якого діє заборона, через незадовільну адаптацію організму до иієєї вправи. Єдиним правильним рішенням у иьому разі є поступове поліпшення адаптації організму до вправи такого виду.

Основним засобом, який забезпечує розвиток адаптаційних процесів, має бути сама “протипоказана" вправа. Не виключати, а дозовано, з урахуванням ступеня наявних порушень $i$ пристосувальних можливостей організму використовувати цю вправу, що становить одне із важливих завдань занять з фізичного виховання у спеціальних медичних груп. Оволодіння новими фізичними вправами і руховими навичками, безумовно, важливо для студентів. Однак безпосередньою, найближчою за часом „віддачею” від навчальних занять з фізичного виховання і має бути підвищення розумової, фізичної працездатності та ліквідація або зменшення впливу залишкових явиш після захворювання.

Ключові слова: дослідження, здоров'я, студенти-першокурсники, психосоматичні, гіподинамія, здоров'язбережувальні технології.

Відомо, що тонус скелетних м'язів відіграє важливу роль у діяльності опороно-рухового апарату людини, тим самим здійснюючи суттєвий вплив на загальний стан організму та його працездатність. У свою чергу велике значення на формування тонічних скорочень на рівні напруження м'язів має 
постава людини (Ю. М. Уфлянд, 1965; М. М. Фарфель, 1956; Є. І. Жуков, В. Б. Ушаков, 1965; В. С. Раєвський, 1971; М. Р. Могендович, К. Л. Гейхман, 1971 та ін.).

Під час трудового процесу, пов'язаному з роботою у положенні сидячи та обмеженим фрізичним навантаженням, стан організму багато у чому залежить від обладнання робочого місця, режиму праці та відпочинку.

Відсутність активної рухової діяльності, статичне напруження м'язів, поєднання із нераціональною робочою позою, несприятливо впливають на загальний стан організму і супроводжується падінням працездатності що чітко виявляється у показниках функціонального стану опорно-рухового апарату [9, $10,11]$.

Вивчення динаміки зміни м'язової сили рук показало, що при тривалому перебуванні сидячи, наприклад, при роботі на комп'ютері, має місце більше виявлене зниження протягом навчального дня студентів сили правої руки (на $5,3 \pm 1,09$ кг; $t=2,19 ; p$ > 0,05) у порівнянні до лівої (на 1,1 \pm 0,31 кг; $t$ = 0,67; $\mathrm{p}<0,5)$. Це, на наш погляд, пов'язано з особливостями робочої пози студентів, яка притаманна їм під час навчальних занять.

Отже, вимушене положення правої руки призводить до постійного напруження м'язів плеча і передпліччя, що, у свою чергу, сприяє розвитку процесів стомлення.

На значення робочої пози у розвитку стомлення при визначеному характері навчальної діяльності студентів вказують також дані, отримані при дослідженні стану м'язового тонусу. Дослідження проводились на симетричних м'язах обох рук і плечового пояс за допомогою міотонометра.

Отримані результати показали, що тривале перебування у малорухливій (сидячій) робочій позі призводить до зниження показників міотонометрії від 3,2 до 2,4 умовних одиниць для м'язових груп правої сторони і від 3,0 до 1,9 умовних одиниць для м'язових груп лівої сторони тулуба. При цьому необхідно відмітити, що рівень тоничного напруження м'язів передпліччя і плечового поясу правої половини тулуба дещо вищий. Такий характер змін, треба вважати, пояснюється тим, що права рука, зазвичай, несе більше рухове навантаження.

Виходячи із вище наведеного та отриманих літературних даних, що свідчать про доцільності включення рухового компоненту в режим праці при розумовій праці $[1,2,3,4,5,6,7,8]$, нами була проведена серія експериментальних досліджень щодо вивчення впливу дозованих фрізичних навантажень на стан м'язового тонусу в умовах напруженої розумової діяльності, яка поєднувалась з вираженою гіподинамією.

Виміри тонусу м'язів виявили, що після введення у режим навчання студентів у якості активного відпочинку фрізкультурних хвилинок спостерігаються певні зміни тонічного напруження м'язів плеча і передпліччя. Після виконання фізичних вправ тонус м'язів дещо підвищується, а рівень його стає більш стійким. Одночасно, отримані дані свідчать, що вплив фізичних вправ викликає більше підвищення тонусу м'язів лівої руки, ніж правої, тобто м'язових груп, які переважно знаходилися у статичному стані. 
Прийнято вважати, що стан загального тонусу організму, у тому числі і м'язового, залежить від тонусу вегетативної нервової системи і, у першу чергу, від їі вищих відділів у корі головного мозку [3, 4, 11]. Під час напруженої розумової праці мозку до активної діяльності підключається не тільки кора великих півкуль, але й уся підкоркова ділянка. Розумове стомлення призводить до порушення корково-підкоркових взаємовідносин, зниженню регулюючого впливу кори, розвитку гальмівних, фразових явищ, що призводить до пригнічення вегетативних центрів, гальмування функції ретикулярної формації стовбура мозку. 3 іншої сторони, при малорухливому статичному стані організму в центри головного мозку надходить менше центр обіжних імпульсів. Зменшення потоку імпульсації та їх «одноманітність» у зв'язку з малою руховою активністю призводить до зниження збудження нервових центрів, у свою чергу рефлекторно знижуючих тонус ретикулярної формації, підкоркових ядер, тобто тонус вегетативної нервової системи, і тим самим сприяє розвитку стомлення [2, 4, 11].

Отримані результати погоджуються 3 даними С.І. Крапівінцева (1971), І. В. Муравова (1965, 1970, 1995), Гандура Арафата (1984), С. І. Присяжнюка $(1984,2001,2011)$ та ін., які довели, що ефект активного відпочинку не обмежується лише стимуляцією працеспроможності стомлених м'язів включення додаткової діяльності нестомлених м'язових груп, сприяє суттєвому покращенню функціонального стану внутрішніх органів і систем організму. Особливе значення має той фракт, що в умовах активного відпочинку при розумовому стомленні спостерігається суттєве підвищення функціонального стану нервових центрів і як наслідок - покращення координаційного механізму м'язів-антагоністів, економізація витрат біоелектричної активності, більш швидке відновлення центральних регуляторних механізмів, одним із показників якого є покращення стану м'язового тонусу.

Висновок. Таким чином, важливим для збереження працездатності $\epsilon$ дотримання правильного чергування праці та відпочинку, тобто процесів збудження та гальмування. Для студентів, праця яких відноситься до розумової, що поєднується з малорухливою робочою поставою, повинна бути передбачена така організація навчальної діяльності, яка включала б активний відпочинок, який попереджує розвиток передчасного стомлення, сприяє підвищенню функціонального стану нервової системи, яка забезпечує збереження розумової працездатності на високому рівні.

\section{Використана література:}

1. Аверьянов В. С., Колесникова Н. Г., Точилов К. С. Физиология труда. Москва, 1967. С. 18.

2. Аршавский И. А. В кн. : Двигательная активность и старенне. Киев : 4-я военная типография, 1969. С. 50-70.

3. Бернштейн Н. А. Очерки по физиологии движений и физиологии активности. Москва : Наука, 1966. $248 \mathrm{c}$.

4. Могендович М. Р. К вопросу о влиянии мышечной работы на кору головного мозга. Проблемы современной физиологии нервной и мыпечной систем. Тбилиси : Из-во АН Груз. ССР, 1956. С. 177-182.

5. Муравов И. В. Активный отдых. Физиология мышечной деятельности, труда и спорта: Руководство по физиологии. Москва : Наука, 1969. С. 357-367. 
6. Муравов И. В., Цисовская Г. А. Оздоровительные эффекты психоэмоциональной активности в стимуляции умствнной работоспособности молодых и пожилых людей. Актуальні проблеми оздоровчої фізкультури, спорту дітей-інвалідів та валеологї в навчальних закладах Украӥни. Матеріали IV Всеукраїнської науково-практичної конференції. Кіровоград, 1996. С. 12-13.

7. Навакатикян А. О., Ковалева А. И. Здоровье и работоспособность при умственном труде. Киев : Здоровье, 1989. 88 с.

8. Присяжнюк С. І. Фізичне виховання : навч. посіб. Київ : Центр учбової літератури, 2008. 504 с.

9. Присяжнюк С. І., Оленєв Д. Г., Парчевський Ю. М. Оздоровча фізична культура студентів вищих навчальних закладів ІТ-технологій. Київ : НУБіП України, 2016. 508 с.

10. Фурманов А. Г., Юспа М. Б. Оздоровительная физическая культура : учебник. Минск : Тесей, 2003. $528 \mathrm{c}$.

11. Ухтомский А. А. Доминанта. М.-Л. : Наука, 1966. 194 с.

\section{References:}

[1] Aver yanov V. S., Kolesnikova N. G., Tochilov K. S. Fiziologiya truda. M., 1967. S. 18.

[2] Arshavskij I. A. V kn..: Dvigatel naya aktivnost’ i starenne. K. : 4-ya voennaya tipografiya, 1969. S. 50-70.

[3] Bernshtejn N. A. Ocherki po fiziologii dvizhenij i fiziologii aktivnosti. M. : Nauka, 1966. $248 \mathrm{~s}$.

[4] Mogendovich M. R. K voprosu o vliyanii my`shechnoj raboty` na koru golovnogo mozga. Problemy` sovremennoj fiziologii nervnoj i my`shechnoj sistem. Tbilisi : Iz-vo AN Gruz. SSR, 1956. S. 177-182.

[5] Muravov I. V. Aktivny`j otdy`kh. Fiziologiya my`shechnoj deyatel 'nosti, truda i sporta: Rukovodstvo po fiziologii. M. : Nauka, 1969. S. 357-367.

[6] Muravov I. V., Czisovskaya G. A. Ozdorovitel`ny`e e`ffekty` psikhoe`moczional noj aktivnosti v stimulyaczii umstvnnoj rabotosposobnosti molody'kh i pozhily'kh lyudej. Aktual'ni problemy` ozdorovchoyi fizkul'tury' sportu ditej-invalidiv ta valeologiyi $v$ navchal'ny`x zakladax Ukrayiny`. Materialy` IV Vseukrayins`koyi naukovo-prakty`chnoyi konferenciyi. Kirovograd, 1996. S. 12-13.

[7] Navakatikyan A. O., Kovaleva A. I. Zdorov`e i rabotosposobnost` pri umstvennom trude. K. : Zdorov`e, $1989.88 \mathrm{~s}$.

[8] Pry`syazhnyuk S. I. Fizy`chne vy`xovannya : navch. posib. K. : Centr uchbovoyi literatury`, 2008. 504 s.

[9] Pry`syazhnyuk S. I., Olenyev D. G., Parchevs`ky`j Yu. M. Ozdorovcha fizy`chna kul’tura studentiv vy`shhy`x navchal’ny`x zakladiv IT-texnologij. K. : NUBiP Ukrayiny`, 2016. 508 s.

[10] Furmanov A. G., Yuspa M. B. Ozdorovitel’naya fizicheskaya kul’tura : uchebnik. Minsk : Tesej, 2003. $528 \mathrm{~s}$.

[11] Ukhtomskij A. A. Dominanta. M.-L. : Nauka, 1966. 194 s.

ОЛЕНЕВД.Г. Влияние активного отдыха на состояние мышечного тонуса при малоподвижной осанке.

По результатам исследований свыме 60,0\% студентов-первокурсников имеют разные психосоматические отклонения в состоянии здоровья и с каждым следующим годом обучения в высшем учебном заведении это количество увеличивается. Актуальной проблемой в подготовке спечиалистов у отрасли телекоммуникационных и информационных технологий является недостаточная двигательная активность, которая содействует интенсивному развитию прочессов гиподинамии. Вследствие этого очевидная необходимость относительно внедрения здоров'язбережувальних технологий в учебный прочесс студентов высших учебных заведений телекоммуникационных и информачионных технологий.

Общеизвестно, что те физические упражнения, к которым организм плохо адаптирован (например, бежал), оказываются самыми ценными в условиях осторожного, сурово дозированного использования. Любое физическое упражнение может быть исключено лишь на некоторое время, после чего ее надо постепенно включать в занятие. Запрет любых упражнений по медииинским показателям через плохое приспособление организма к их выполнению может касаться тех движений, которые не имеют прикладного значения, например, некоторые гимнастические упражнения, как “шпагат”. Ни одно физическое упражнение, которое имеет прикладное значение, не может быть противопоказанным вообще, без определения периода, на протяжении которого действует запрет, через 
неудовлетворительную адаптацию организма к этому упражнению. Единственньм правильным решениям в этом случае есть постепенное улучиение адаптации организма к упражнению такого вида.

Основным средством, которое обеспечивает развитие адаптационных процессов, должно быть само “противопоказанное” упражнение. Не исключать, а дозировано, с учетом степени имеюшихся нарушений и пристосувальних возможностей организма использовать это упражнение, которое представляет одно из важных заданий занятий из физического воспитания у специальных медицинских групп. Овладение новыми физическими упражнениями и двигательными навыками, безусловно, важно для студентов. Однако непосредственной, ближайтей по времени “отдачей” от учебных занятий по физическом воспитании и должно быть повышение умственной, физической работоспособности и ликвидация или уменьшение влиянию остаточных явлений после заболевания.

Ключевые слова: исследование, здоровье, студенты-первокурсники, психосоматические, гиподинамия, здоров'язбережувальні технологии.

OLENIEV D. The influence of active rest on the state of muscle tonus during low-mobile position.

According to the research of first-year students, more than $60 \%$ have different psychosomatic deviations in health and this number increases every subsequent year of studying in a University. The urgent problem in training of specialists in the field of telecommunications and information technologies is the lack of physical activity that promotes the intensive development of processes of hypodynamia. Consequently, it is definitely needed to implement health-saving technologies in students' educational process of University of telecommunications and information technologies.

It is known that those physical exercises, for which the organism is badly adapted (eg, running), are the most valuable in terms of a careful, strictly dosed usage. Any physical exercise may be removed only for a while, then it should be gradually included in the studying process. The forbiddance of any physical exercise because of bad adaptation of the organism to their implementation may concern those movements that have no practical importance, for example, some gymnastic exercises, such as "twine". Any physical exercise, that has a practical value, even with a poor adaptation of an organism, can not be contraindicated without specifying the period of a ban. The only correct decision in this case is the gradual improvement of adaptation to this type of exercise.

The main tool to provide a development of adaptive process is the "contraindicated" exercise by itself. Thus, the one of the important tasks of physical education of students of special medical groups is not to not exclude the exercise, but to give it dosed, depending of the degree of existing violations and adaptive capacity of the body. A mastering of new physical exercises and movement skills is definitely important for students. However, the direct, immediate impact of physical education studying should be an improvement of mental, physical capacity and the elimination or reduction of residual effects of illness.

Keywords: research, health, first-year students, psychosomatic, hypodynamia, health-saving technologies. 